\title{
Addition of Chromium and its effect on the microstructure and mechanical properties of laser- coated high carbon ferrochrome alloy on mild steel
}

Basiru Philip Aramide ( $\sim$ abashiruphilip@gmail.com )

Tshwane University of Technology SA https://orcid.org/0000-0002-6488-1287

\section{Patricia Popoola}

Tshwane University of Technology SA

Rotimi Sadiku

Tshwane University of Technology SA

Tamba Jamiru

Tshwane University of Technology SA

\section{Sisa Pityana}

National Laser Centre, Council for Scientific and Industrial Research

\section{Research Article}

Keywords: Microstructural modification, laser cladding, chromium addition

Posted Date: August 2nd, 2021

DOl: https://doi.org/10.21203/rs.3.rs-769792/v1

License: (c) (i) This work is licensed under a Creative Commons Attribution 4.0 International License. Read Full License 


\section{Abstract}

Laser cladding is an additive manufacturing technology that can be utilized in surface strengthening, modification, and repair of components that are subjected to adverse working conditions. This can be accomplished by the addition of functionally graded material with a remarkable limit to enhancing an engaged credited property of monolithic material that is superior and better than its monolithic counterparts. Chromium addition to the microstructure of components has been found to increase the electrochemical stability, high-temperature strength and corrosion resistance of laser additive manufactured components. The current study investigates the effect of the extra addition of chromium on the hardness and microstructure of laser coated high carbon ferrochrome FeCrV15 on steel baseplate.

\section{Introduction}

Laser cladding is a surface fortification, adaptation and repairing technology. This manufacturing technique has benefits, such as minor stress deformation, low heat affected zone (HAZ), low dilution ratio and enhanced metallurgical bond of the clad to the substrate. It has great application possibilities in enhancing the corrosion and wear resistance of materials through the incorporation of choice functionally graded materials that meet the required targeted property (Zhang et al., 2014c, Yan et al., 2010, Zhang et al., 2014a, Aramide et al., 2021). This makes it to be increasingly applied in surface and manufacturing engineering applications. A great variety of materials can be, placed on a substrate using laser cladding through powder infusion, forming layer(s) with thicknesses ranging between 0.05 to $2 \mathrm{~mm}$ and widths as small as $0.4 \mathrm{~mm}$ (Toyserkani et al., 2004).

Nickel, iron, and cobalt-based alloy powders are broadly utilized as cladding materials. Nickel and cobaltbased coatings have great corrosion resistance and high-temperature performance but are rare and expensive. Iron-based alloy (mild steel, carbon steel, boron steel, etc.), are a lot less expensive, readily available (Zhang et al., 2014b) and are generally utilized in the manufacturing of soil cultivating and excavating components of tillage and mining tools, but with poorer corrosion and wear resistance compared to cobalt and nickel (Aramide et al., 2021). Nevertheless, high carbon ferrochrome exhibits both high hardness and heat resistance. Apart from its abundant availability, ferrochrome is profitable in its generally low cost (Gu et al., 2020).

Chromium is generally, utilized as one of the highly effective alloy components and it is notable for upgrading the electrode capabilities and corrosion resistance of nickel-based and iron-based alloys. Likewise, a strong arrangement of $\mathrm{Cr}$ atoms can advance the quick development of a solid, unchanging, and electrochemically stable, inactive chromium oxide film (Carmezim et al., 2005, Alamr et al., 2006, Zhou et al., 2013). It is likewise broadly detailed that Cr-alloying noticeably helps in upgrading mechanical properties like durability, malleability and high-temperature strength (Coutu et al., 2000, Cai et al., 2003, Wiengmoon et al., 2011, Bai et al., 2013). Haupt and Strehblow (Haupt and Strehblow, 1995) brought up that the inclusion of $\mathrm{Cr}$ in $\mathrm{Fe}-\mathrm{Cr}$ alloy combination lowered the density of corrosion current and movad tho nittinn notontial tn maro hnnourahlo nualities. Cai et al., (Cai et al., 2003, Cai et al., 2004) Loading [MathJax]/jax/output/CommonHTML/fonts/TeX/fontdata.js 
detailed that a moderate measure of $\mathrm{Cr}$ could enhance microstructure, upgrade hardness, and could likewise fundamentally increase corrosion and wear resistance of $\mathrm{Ni}_{2} \mathrm{Si}$ and $\mathrm{NiSi}$ laser cladding coatings (Zhang et al., 2014c). In our previous work, high carbon ferrochrome FeCrV15 was found to upgrade both the microstructure and hardness of the steel baseplate. The current study investigates the effect of the extra addition of chromium on microstructure and hardness of high carbon ferrochrome FeCrV15 clad.

\section{Materials And Methods}

The cladding was systematically done layer upon layer on a steel baseplate of dimensions $100 \mathrm{~mm} x$ $100 \mathrm{~mm} \times 5 \mathrm{~mm}$ in the facility of the Council for Scientific and Industrial Research (CSIR), Pretoria South Africa. The materials, chromium and FeCrV15 powders, used for the study were purchased from Samaterial of the United States and WearTech of South Africa respectively, with $99 \%$ purity, which was used without change as gotten, see Tables 1 and 2 for the powders' chemical composition by weight and Table 3 the base plate's chemical composition.

The coatings with five tracts, three layers and $50 \%$ overlap were accomplished by using a $3 \mathrm{~kW}$ Continuous Wave (CW) Rofin Sinar Nd:YAG laser system, with a laser beam power of $1200 \mathrm{~W}$ and a scanning speed of $8 \mathrm{~m} / \mathrm{s}$. The powders were deposited in-situ on the substrate by a DPSF-2 type coaxial powder feeder at $6 \mathrm{~g} / \mathrm{min}$ for FeCrV15 powder for sample A. Moreover, the FeCrV15 and chromium powder were, co-added at $6 \mathrm{~g} / \mathrm{min}$ and $0.4 \mathrm{~g} / \mathrm{min}$, respectively, onto the substrate, for sample B. All assisted by $2 \mathrm{~L} / \mathrm{min}$ and $15 \mathrm{~L} / \mathrm{min}$ flow of argon as the carrying and shielding gas, respectively. Figure 1 shows the SEM micrographs of the powder materials used in the experiment.

Table 1

Composition by weight of the high carbon ferrochrome powder

\begin{tabular}{|llllllll|}
\hline Element & C & Mo & Fe & Mn & Cr & Si & V \\
\hline Weight\% & 4.5 & 1.3 & Balance & 1.1 & 14.0 & 1.1 & 15.4 \\
\hline
\end{tabular}

Table 2

Composition by weight of chromium powder

\begin{tabular}{|lllll|}
\hline Element & $\mathbf{C}$ & $\mathbf{0}$ & $\mathrm{Al}$ & $\mathrm{Cr}$ \\
\hline Weight\% & 3.62 & 8.00 & 1.16 & 87.22 \\
\hline
\end{tabular}

Table 3

Composition by weight of the base plate

\begin{tabular}{|llllll|}
\hline Element & C & Al & Si & Mn & Fe \\
\hline Weight\% & 2.54 & 0.17 & 0.12 & 1.32 & Balance \\
\hline
\end{tabular}

The samples were cross-sectioned, ground, polished, and etched with modified Fry's Reagent $\left(150 \mathrm{ml} \mathrm{H}_{2} \mathrm{O}\right.$,

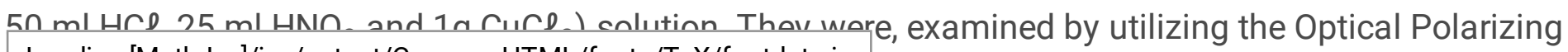
Loading [MathJax]/jax/output/CommonHTML/fonts/TeX/fontdata.js 
Microscope (OPM) and Scanning Electron Microscope, equipped with an Energy Dispersive Spectroscopy (SEM/EDS). The X-ray diffractometer with Cu radiation and a parallel beam of $2 \mathrm{~mm}$ diameter was utilized for X-ray diffractive analysis of the samples. The hardness profile of the clad was done with a fully computerized FM-ARS900 Vickers testing machine (Future-Tech Corp., Kanagawa, Japan) with a load of $2.94 \mathrm{~N}$. This was taken from the top of the clad down to the core of the substrates at a spacing of $200 \mu \mathrm{m}$

\section{Experimental Results And Analysis}

The cladded samples are, represented in Fig. 2. The cladded samples are crack-free, based on visual observation of the cross-sectional surfaces with the aid of an optical microscope and SEM. Both clad show similarity in the deposition rate and dilution ratio (Günther and Bergmann, 2020) with minimal porosity, which may be due to the gas inclusions, which are highly dependent on the solidification geometry.

The SEM micrographs of the samples are, represented in Fig. 3. As identified in our previous work, the primary vanadium carbides VCs is the 'fishbone or rodlike precipitate and the star-flower-like structure', see position 1 in Figs. 3 and 4. Position 2 represent the agglomeration of eutectic VCs precipitate forming primary VCs. The combination of chromium-vanadium carbides phases encircling the VCs precipitates, signifying martensite, see position 3. Position 4 indicates the chromium-rich eutectic lamellar microstructure, while the portion not affected by the etchant is the retained austenite, see position 5; this is confirmed by the additional SEM-EDS investigation results of both sample $A$ and $B$ as represented in Tables 3 and 4, respectively. It was, observed that positions 1 and 2 had the highest $V$ content, which further established the precipitation of vanadium carbide.

Position 4 was also confirmed to be chromium-rich eutectic carbide with the highest percentage weight of chromium for sample A, $21 \%$ and for sample B, $20 \%$. Moreover, the extra addition of chromium to sample $B$ is shown in the higher weight composition of chromium in all the positions under observation as compared to sample A, see Tables 3 and 4 .

Furthermore, a fine grain formation was observed in the microstructure of the clad, closer to the substrate, see Fig. 4. The precipitation of the carbides (primary VCs, eutectic VCs, and Cr-rich) are of smaller grain size in comparison to both the middle and the top of the clad. For instance, the grain size of the primary VCs at the middle and the top of the clad are approximately five times and ten times bigger than at the bottom of the clad, respectively. The precipitation of the carbides was observed to be evenly, dispersed in the lower portion of the clad. This is, observed in grain refinement because of better heterogeneous nucleation and thus, upgraded mechanical feedback was noticed (Aramide et al., 2020, Owsiak, 1997, Aramide et al., 2021) in the higher hardness of the lower portion of the clad as compared to the upper portion as shown in the hardness profile plot represented by Fig. $5 \mathrm{~b}$. 
Moreover, the observation of the optical microscope examination of both samples shows the even distribution of the primary vanadium carbides (sample B) and that the eutectic chromium-vanadium carbide, is perfectly dissolved and evenly dispersed into the grain boundary of the microstructure (samples A \& B) of the lower portion of the clad (Gualtieri, 2016). This portion comprises of the dilution zone and zone with early Primary VC's precipitation. This improves the grain refinement and heterogeneous nucleation of the microstructure (Figs. 6a, b \& c).

This could be said to be responsible for a higher hardness of the lower portion of the clads, see Figs. 5a \& b. However, in the microstructure of the middle portion of the clads, sample A shows evenly and densely distributed primary VCs, eutectic VCs, Cr-rich carbide (Fig. 6c), while the carbide-rich precipitates are sparsely distributed in sample B, see Fig. $6 \mathrm{~d}$. The same is observed in the micrographs of the upper portion of the clads, see Fig. $6 e \& f$, for $A$ and $B$, respectively. It is suspected that the microstructure of sample $A$ is more martensitic, as compared to sample $B$ where the austenitic microstructure is suspected to be predominant due to the lower hardness of the middle and upper portion of the clad. This is attributed to the extra chromium addition in the microstructure of the clad. The average hardness of 835 HV 0.3 and 553 HV 0.3 was, observed for samples A and B, respectively. Moreover, the XRD result (see Fig. 7) showed that the austenitic iron ( $\gamma \mathrm{Fe}$ ) and chromium element diffraction are, identified with very high peaks in sample $B$ result. This is an indication of a higher volume fraction of austenite and thus a lesser martensitic matrix with a lower expected hardness (Leunda et al., 2011). VCs and $\mathrm{Cr}_{3} \mathrm{C}_{2}$ have peaks that are very low compare to sample $A$, this explains the sparse distribution of these phases in the microstructure of sample B. It is believed that sample B will be of higher corrosion resistance due to the significant presence of the austenite. The result also shows martensitic iron together with higher and more peaks of both $\mathrm{VCs}$ and $\mathrm{Cr}_{3} \mathrm{C}_{2}$ in sample $\mathrm{A}$ when compared to sample $\mathrm{B}$.

\section{Summary And Conclusion}

The coatings of high carbon ferrochrome (FeCrV15) + Chromium (B) and high carbon ferrochrome (A) developed by laser cladding have been studied. A major difference was observed in both the hardness and microstructures of the coatings obtained.

The addition of extra chromium to the coatings resulted in a higher percentage of austenite in the matrix and lowered the precipitation of both $\mathrm{Cr}$-rich and vanadium carbide in the microstructure. This invariably resulted in lowering the hardness of the claded sample.

The hardness of roughly 835 HV 0.3 and 553 HV 0.3 was observed for samples A and B respectively, both being more heterogeneous as a result of the variation in the carbide precipitation.

These would be further study to see the effect of this variation in the observed hardness and macrostructures of the clads on its abrasive and corrosive wear.

\section{Declaratinns}

Loading [MathJax]/jax/output/CommonHTML/fonts/TeX/fontdata.js

Page 5/13 


\section{Declaration of Competing Interest}

The authors declare that there is no known contending monetary interests or individual connections that might have influenced this work.

\section{Acknowledgement}

The authors acknowledge the support from Tshwane University of Technology (TUT), Pretoria, South Africa, without which this work would not have been possible.

\section{References}

ALAMR, A., BAHR, D. F. \& JACROUX, M. 2006. Effects of alloy and solution chemistry on the fracture of passive films on austenitic stainless steel. Corrosion Science, 48, 925-936.

ARAMIDE, B., PITYANA, S., SADIKU, R., JAMIRU, T. \& POPOOLA, P. 2021. Improving the durability of tillage tools through surface modification-a review. The International Journal of Advanced Manufacturing Technology.

ARAMIDE, B. P., POPOOLA, A. P. I., SADIKU, E. R., ARAMIDE, F. O., JAMIRU, T. \& PITYANA, S. L. 2020. WearResistant Metals and Composites. In: KHARISSOVA, O. V., MARTÍNEZ, L. M. T. \& KHARISOV, B. I. (eds.) Handbook of Nanomaterials and Nanocomposites for Energy and Environmental Applications. Cham: Springer International Publishing.

BAI, Y., XING, J., MA, S., HUANG, Q., HE, Y., LIU, Z. \& GAO, Y. 2013. Effect of 4wt.\% Cr on microstructure, corrosion resistance and tribological properties of Fe3Al-20wt.\%Al203 composites. Materials Characterization, 78, 69-78.

CAI, L. X., WANG, C. M. \& WANG, H. M. 2003. Laser cladding for wear-resistant Cr-alloyed Ni2Si-NiSi intermetallic composite coatings. Materials Letters, 57, 2914-2918.

CAI, L. X., WANG, H. M. \& WANG, C. M. 2004. Corrosion resistance of laser clad Cr-alloyed Ni2Si/NiSi intermetallic coatings. Surface and Coatings Technology, 182, 294-299.

CARMEZIM, M. J., SIMÕES, A. M., MONTEMOR, M. F. \& CUNHA BELO, M. D. 2005. Capacitance behaviour of passive films on ferritic and austenitic stainless steel. Corrosion Science, 47, 581-591.

COUTU, L., CHAPUT, L. \& WAECKERLE, T. 2000. 50.50 FeNi permalloy with Ti and Cr additions for improved hardness and corrosion resistance. Journal of Magnetism and Magnetic Materials, 215-216, 237-239.

GU, J., LI, R., CHEN, S., ZHANG, Y., CHEN, S. \& GU, H. 2020. Microstructure and Wear Behavior of Laser Cladded Ni45 + High-Carbon Ferrochrome Composite Coatings. Materials, 13, 1611.

GUALTIERI, T. 2016. Direct Laser Deposition of Porous Structures and Gradient Metal-ceramic Composite Loading [MathJax]/jax/output/CommonHTML/fonts/TeX/fontdata.js 
GÜNTHER, K. \& BERGMANN, J. P. 2020. Influencing Microstructure of Vanadium Carbide Reinforced FeCrVC Hardfacing during Gas Metal Arc Welding. Metals, 10, 1345.

HAUPT, S. \& STREHBLOW, H. H. 1995. A combined surface analytical and electrochemical study of the formation of passive layers on FeCr alloys in 0.5 M H2SO4. Corrosion Science, 37, 43-54.

LEUNDA, J., SORIANO, C., SANZ, C. \& NAVAS, V. G. 2011. Laser Cladding of Vanadium-Carbide Tool Steels for Die Repair. Physics Procedia, 12, 345-352.

OWSIAK, Z. 1997. Wear of Symmetrical Wedge-Shaped Tillage Tools. Soil and Tillage Research, 43, 295308.

TOYSERKANI, E., KHAJEPOUR, A. \& CORBIN, S. F. 2004. Laser cladding, CRC press.

WIENGMOON, A., PEARCE, J. T. H. \& CHAIRUANGSRI, T. 2011. Relationship between microstructure, hardness and corrosion resistance in $20 \mathrm{wt} . \% \mathrm{Cr}, 27 \mathrm{wt} . \% \mathrm{Cr}$ and $36 \mathrm{wt} . \% \mathrm{Cr}$ high chromium cast irons. Materials Chemistry and Physics, 125, 739-748.

YAN, H., WANG, A., XU, K., WANG, W. \& HUANG, Z. 2010. Microstructure and interfacial evaluation of Cobased alloy coating on copper by pulsed Nd:YAG multilayer laser cladding. Journal of Alloys and Compounds, 505, 645-653.

ZHANG, H., YONG, Z., ZENGDA, Z. \& CHUANWEI, S. 2014a. Effects of CeO2 on microstructure and corrosion resistance of TiC-VC reinforced Fe-based laser cladding layers. Journal of Rare Earths, 32, 1095-1100.

ZHANG, H., ZOU, Y., ZOU, Z. \& SHI, C. 2014b. Effects of chromium addition on microstructure and properties of TiC-VC reinforced Fe-based laser cladding coatings. Journal of Alloys and Compounds, $614,107-112$.

ZHANG, Y., ZUO, T. T., TANG, Z., GAO, M. C., DAHMEN, K. A., LIAW, P. K. \& LU, Z. P. 2014c. Microstructures and properties of high-entropy alloys. Progress in Materials Science, 61, 1-93.

ZHOU, Y., CHEN, J., XU, Y. \& LIU, Z. 2013. Effects of Cr, Ni and Cu on the Corrosion Behavior of Low Carbon Microalloying Steel in a Cl- Containing Environment. Journal of Materials Science \& Technology, 29, 168174.

\section{Figures}



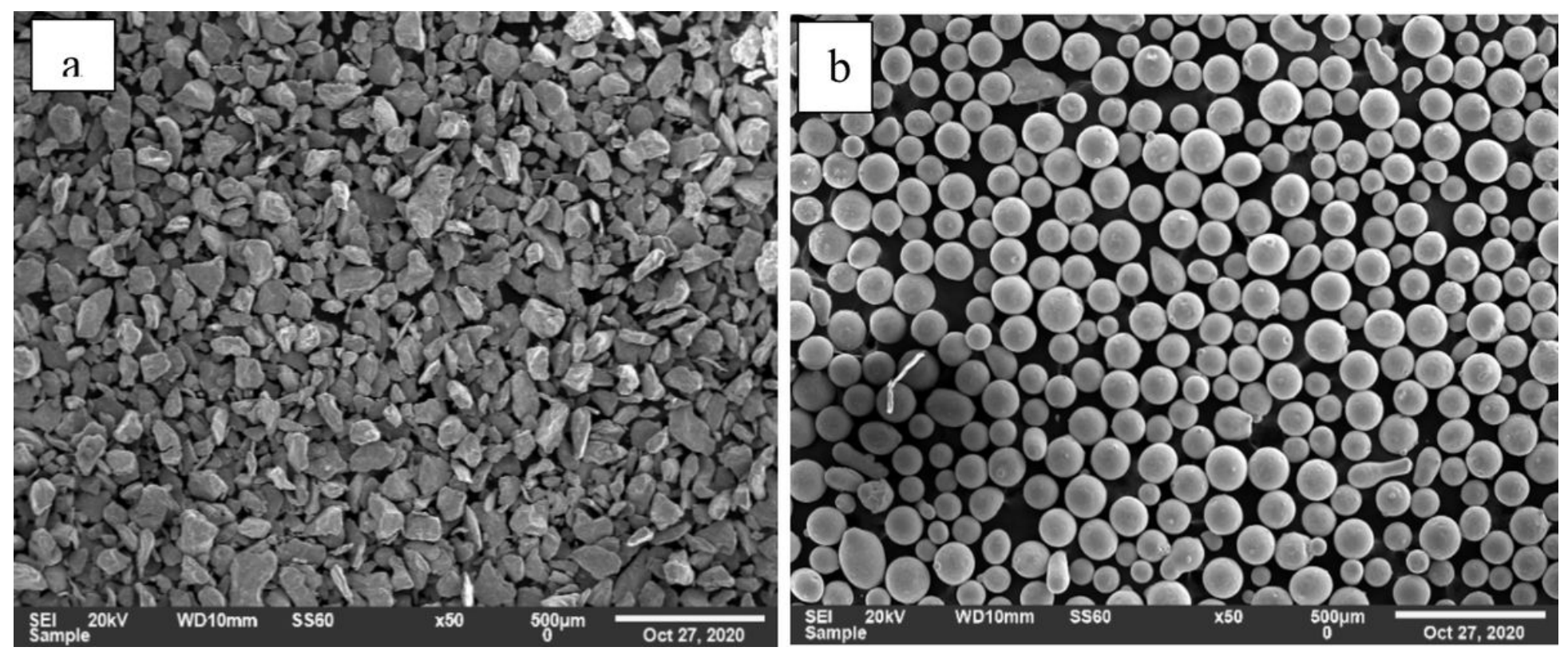

Figure 1

SEM Micrograph of powder used in the study a) Chromium powder, b) High carbon ferrochrome FeCrV15 powder

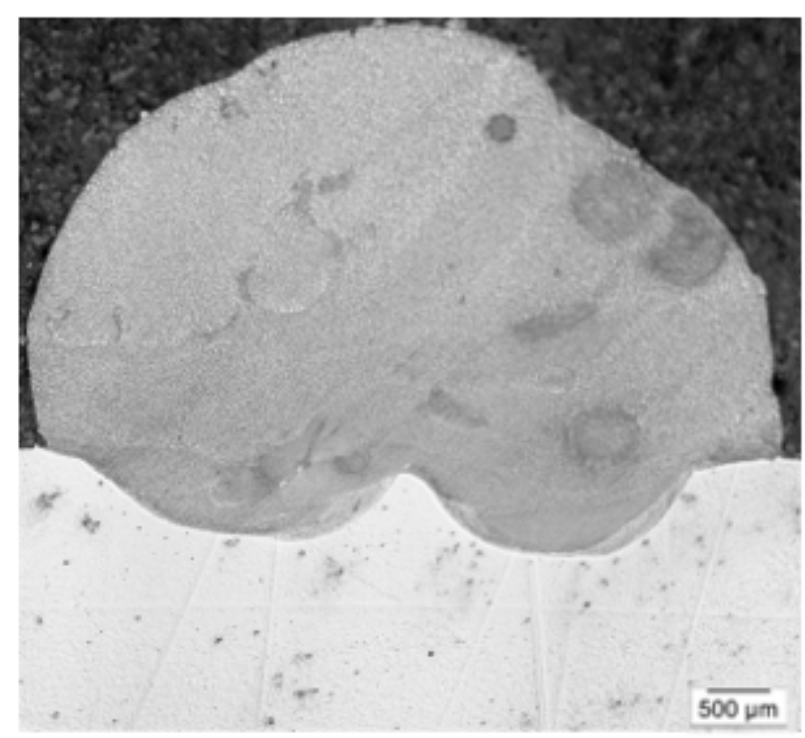

Sample A

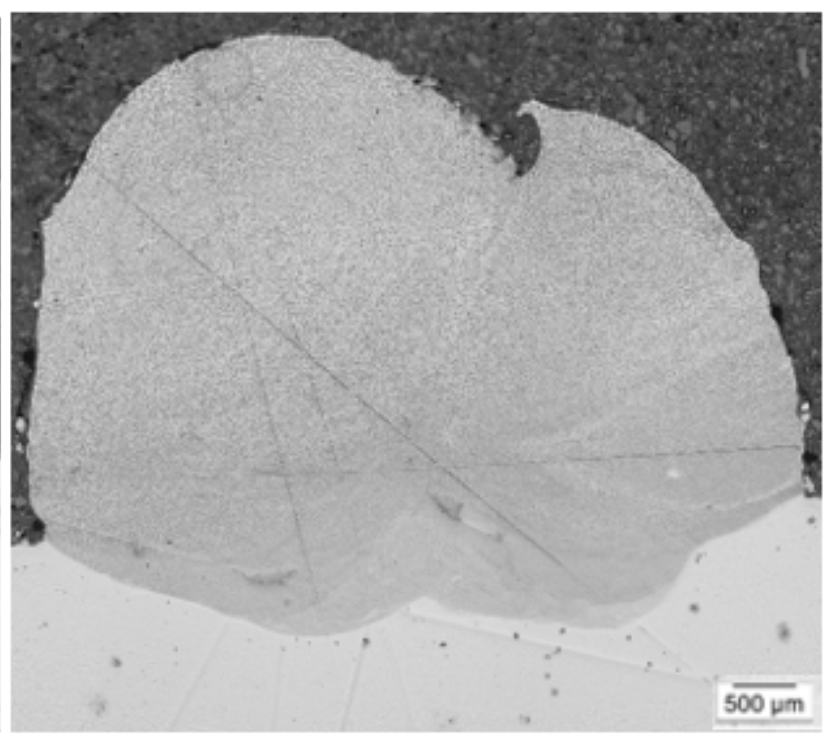

Sample B

Figure 2

Pictorial representation of the clads 


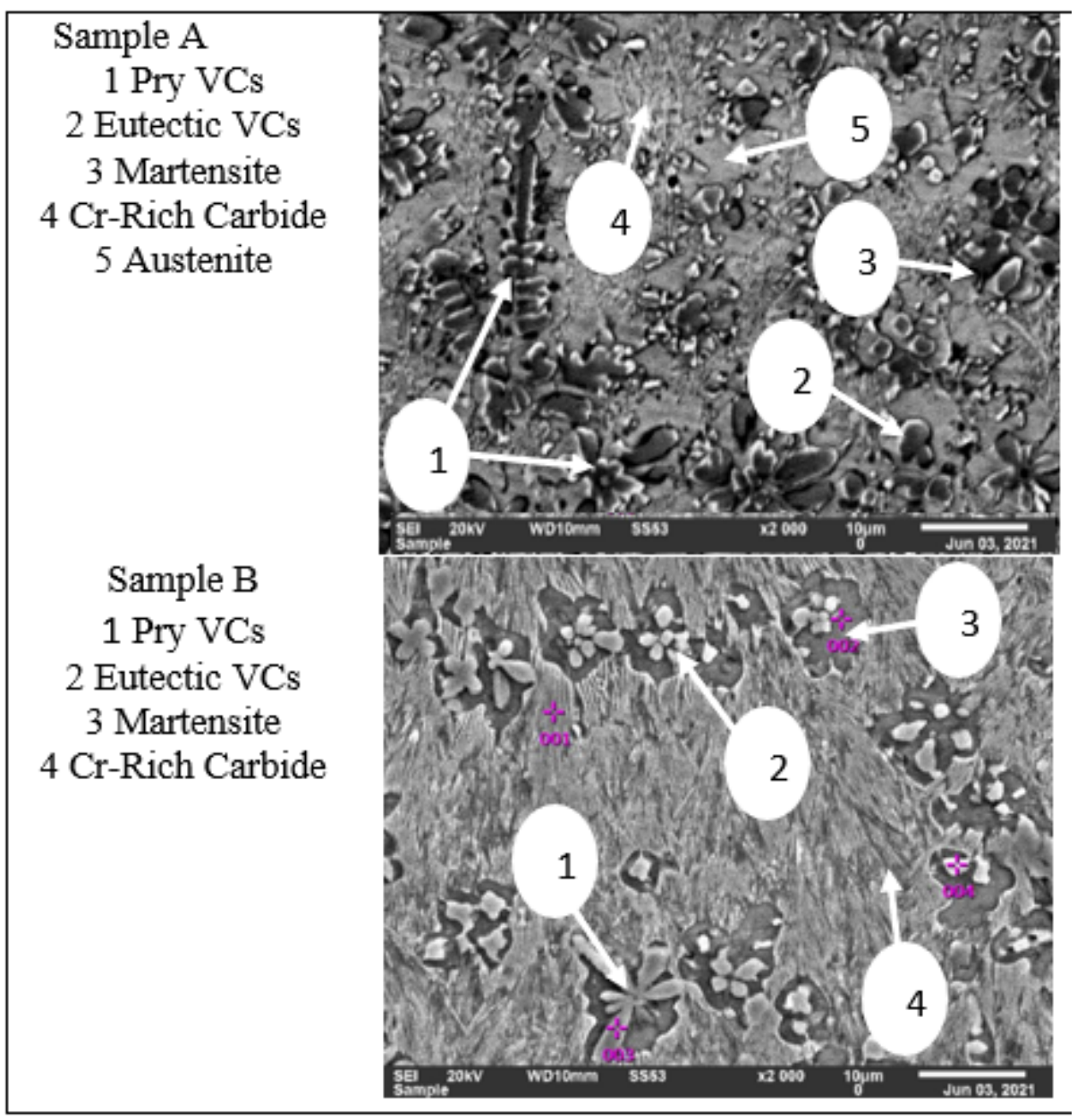

Figure 3

The micrograph of both samples A \& B 
bottom of the clad close to the substrate

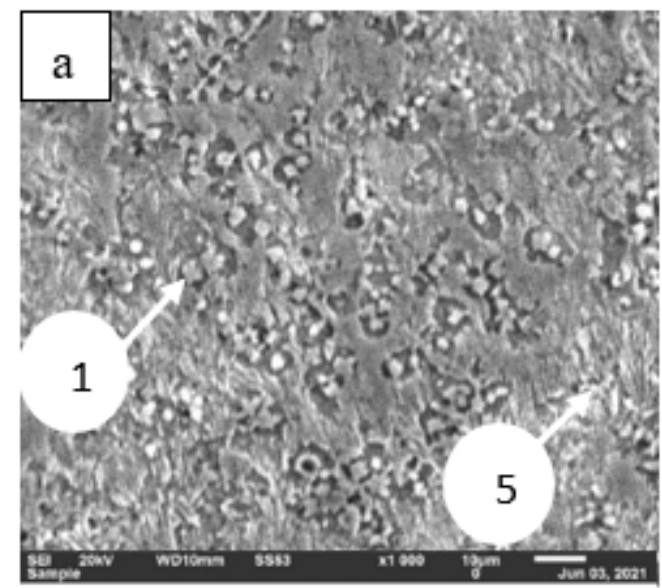

middle of the

clad

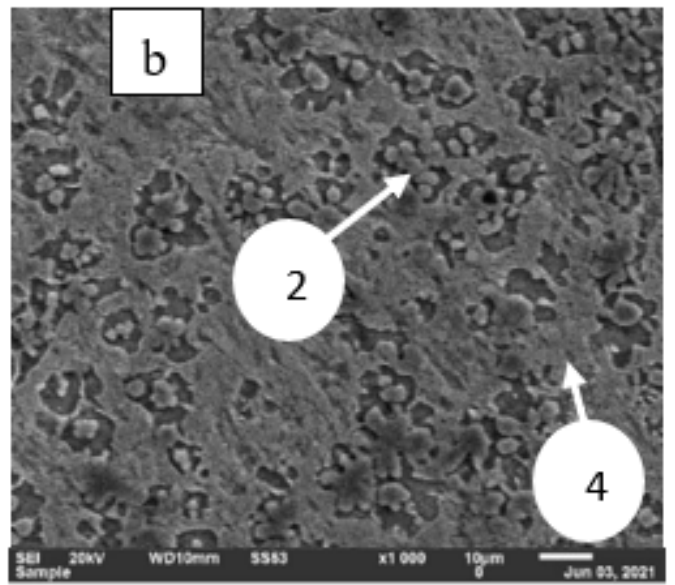

top of the clad

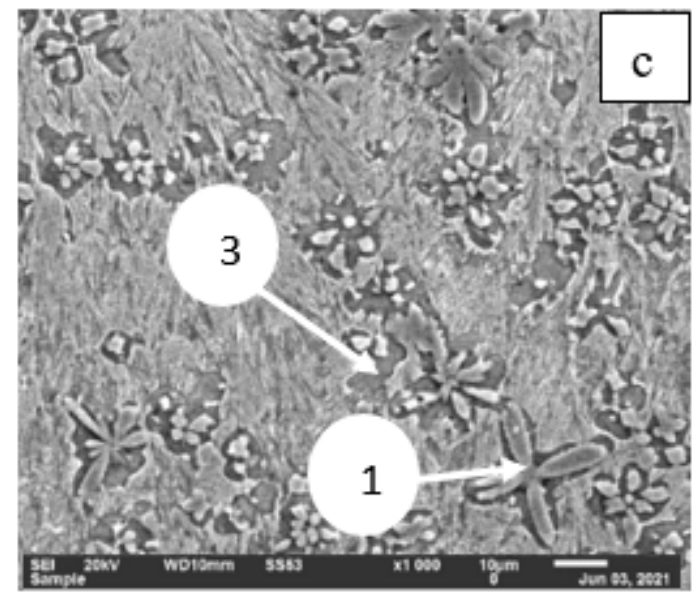

Figure 4

The representation of sample B from the bottom of the clad close to the substrate to the top of the clad 

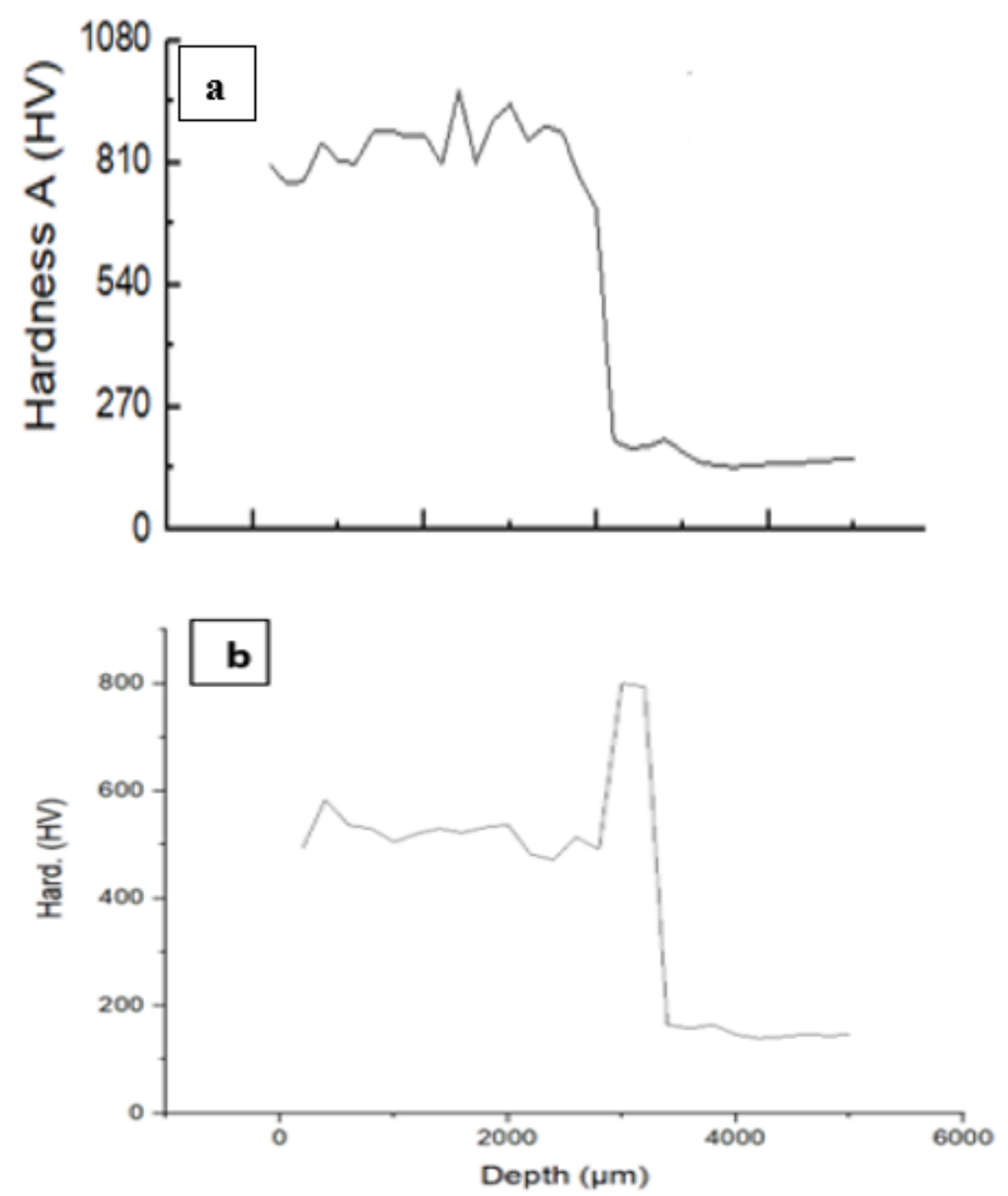

Figure 5

Hardness profile of the Samples a), Sample A b) Sample B 

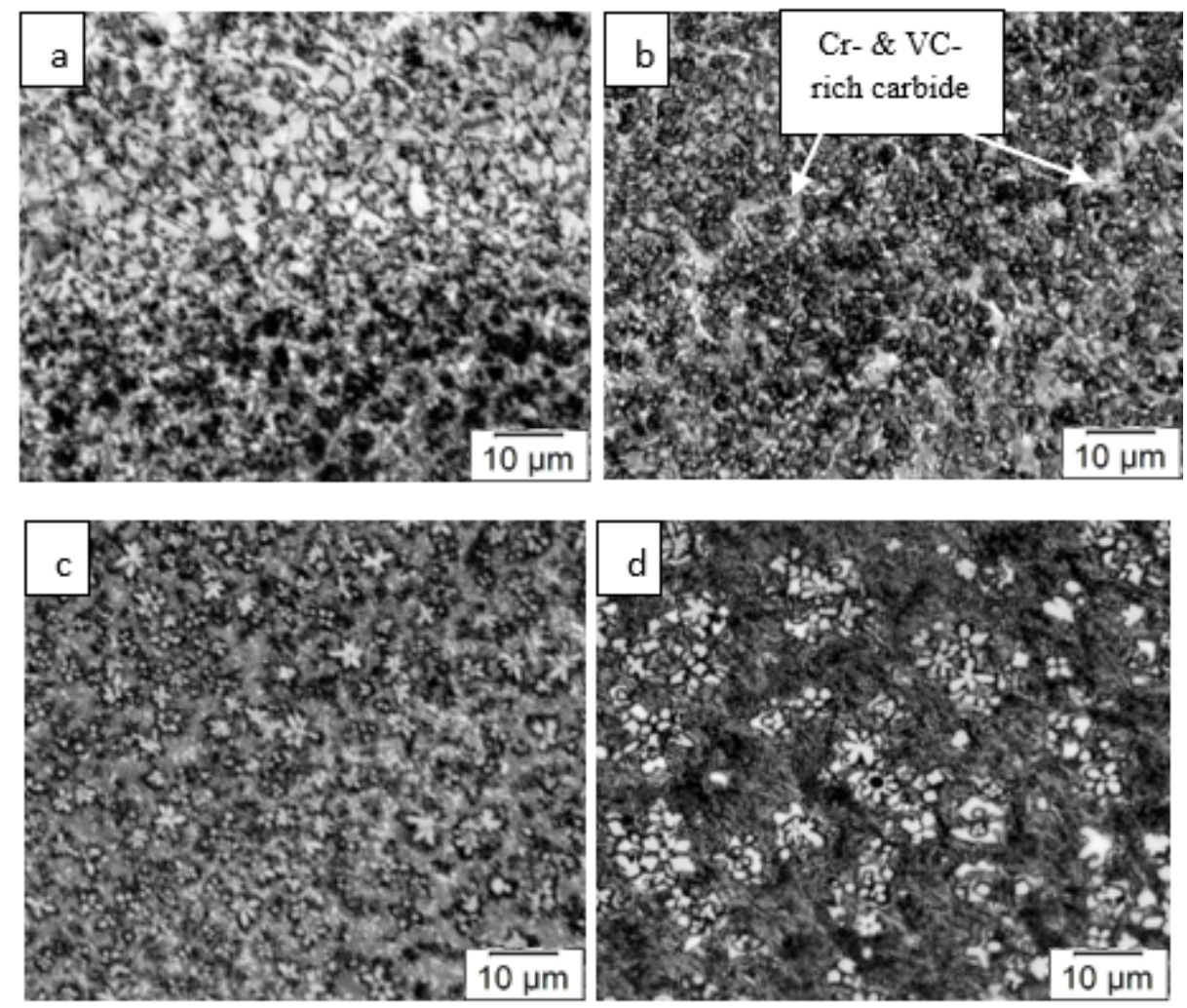

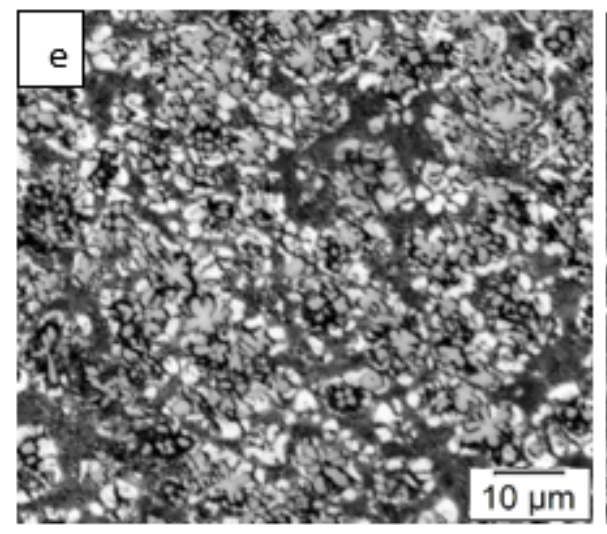

Sample A

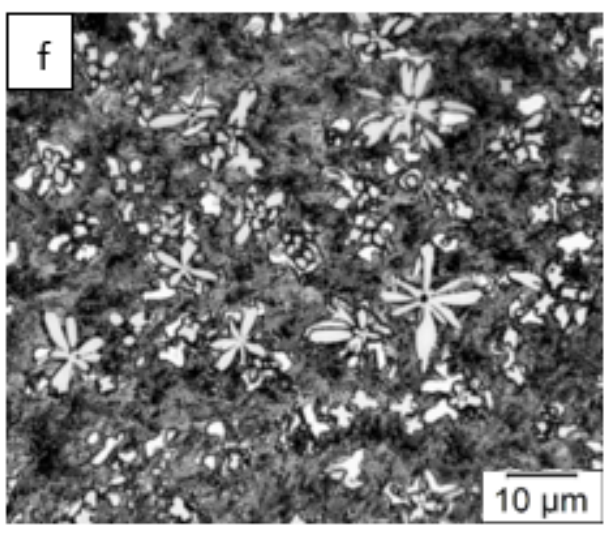

Sample B

\section{Figure 6}

The representation of samples $A$ and $B(a=$ bottom, $C=$ middle and $e=$ top for sample $A \& b=$ bottom, $d=$ middle and $\mathrm{f}=$ top for sample $\mathrm{B}$ ) 


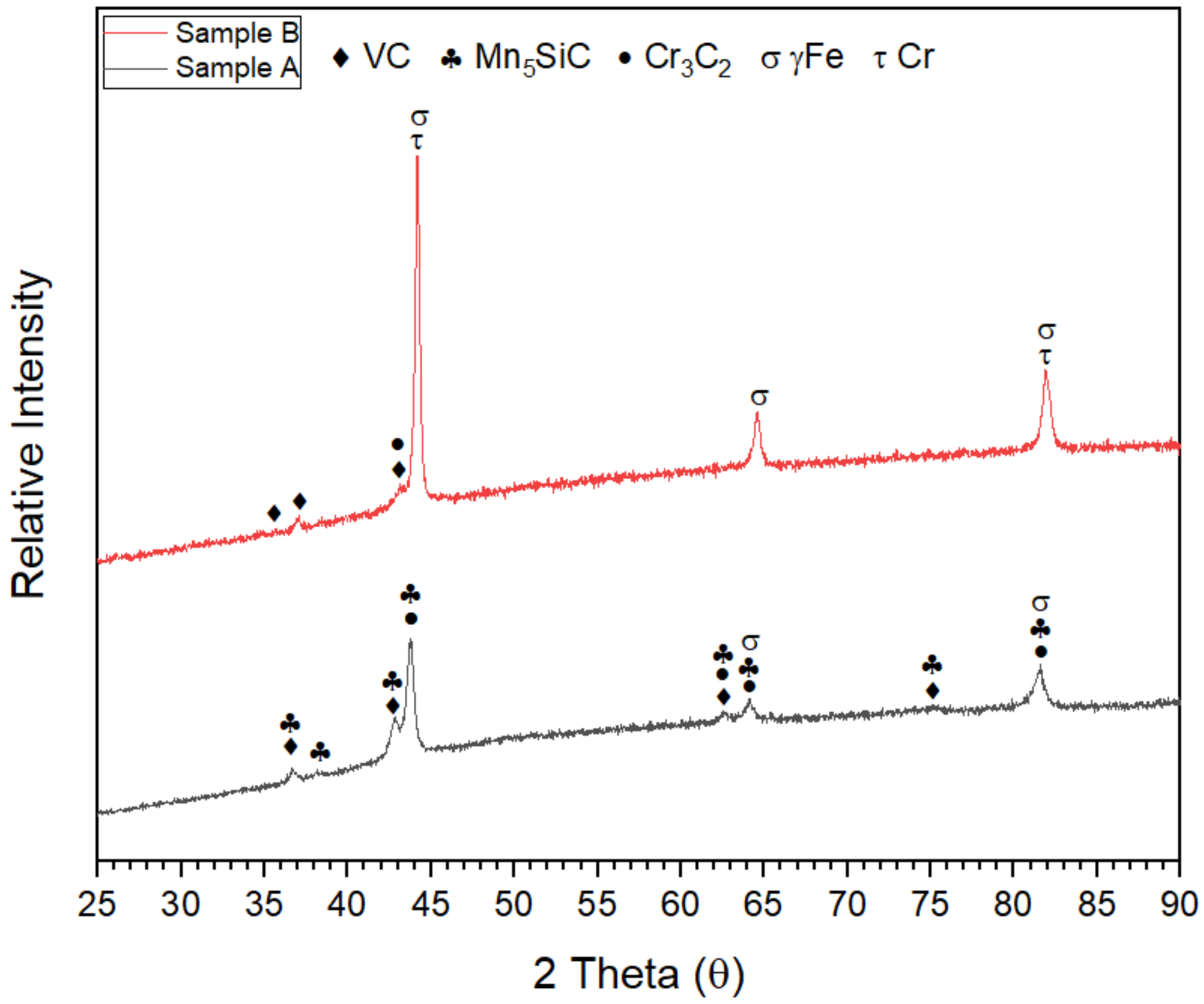

Figure 7

XRD Plot of samples A and B 